\title{
Low serum antibacterial activity coincides with increased prevalence of shell disease in blue crabs Callinectes sapidus
}

\author{
Edward J. Noga ${ }^{1}$, David P. Engel ${ }^{2}$, Thomas W. Arroll ${ }^{3,}{ }^{*}$, Sean McKenna ${ }^{4}$, \\ Marie Davidian ${ }^{5}$ \\ ${ }^{1}$ North Carolina State University College of Veterinary Medicine, 4700 Hillsborough Street, Raleigh, \\ North Carolina 27606, USA \\ ${ }^{2}$ National Marine Fisheries Service, Southeast Fisheries Center, Beaufort Laboratory, Beaufort, \\ North Carolina 28516-9722, USA \\ ${ }^{3}$ North Carolina State University College of Veterinary Medicine, 4700 Hillsborough Street, Raleigh, \\ North Carolina 27606, USA \\ ${ }^{4}$ Department of Statistics, North Carolina State University, PO Box 8203, Raleigh, North Carolina 27695-8203, USA
}

\begin{abstract}
We provide epidemiological evidence that shell disease, a very common problem of crustaceans in polluted environments, coincides with low serum antibacterial activity. In commercially important blue crabs Callinectes sapidus from the Albemarle-Pamlico Estuary, North Carolina, USA, we identified potent antibacterial activity which was active against most of the bacteria inhabiting the shell of both clinically normal crabs as well as those with shell disease. Clinically normal blue crabs from riverine sites, presumed to be at high risk for developing shell disease, had as little as one-fifth the antibacterial activity of crabs from more oceanic control sites, which had low prevalence of shell disease. Crabs with shell disease had lower serum antibacterial activity than cohorts without shell disease from the same geographic site. This antibacterial activity may be an important mechanism protecting crabs against shell disease and may be a useful biomarker of blue crab health.
\end{abstract}

KEY WORDS: Invertebrate immunity $\cdot$ Bactericidins $\cdot$ Bacterial disease

\section{INTRODUCTION}

The blue crab Callinectes sapidus supports an important sport and commercial fishery along the eastern and Gulf coasts of the United States. Recently, shell disease epidemics have caused considerable concern about the health of blue crab populations in the Albemarle-Pamlico Estuary, North Carolina, USA (Fig. 1 in Rader et al. 1987, McKenna et al. 1988). Shell disease is a common syndrome in decapod crustaceans that produces various types of erosive lesions on the shell (Johnson 1983, Sindermann \& Lightner 1988). High prevalence of shell disease has been associated with stressful environments, such as intensive aqua-

- Present address: Dept of Pathobiology, University of Washington School of Medicine, Seattle, Washington 95818, USA culture (Sindermann 1988), impounded populations (Taylor 1948), or polluted natural environments (Gopalan \& Young 1975, Young \& Pearce 1975). Shell disease can also be experimentally induced by exposure of crustaceans to sewage sludge (Young \& Pearce 1975). These data suggest that shell disease may be a useful biomarker of environmental degradation (Murchelano 1982, Sindermann 1989, 1990).

Despite the importance and ubiquity of shell disease, its pathogenesis has been uncertain. It has been associated with infection of the shell by various microbes, especially bacteria (Johnson 1983, Sindermann 1989). Indeed, multiple agents having different pathogenic capabilities may be needed for full expression of the disease (Cipriani et al. 1980). Mechanical shell damage followed by the invasion of shell-degrading bacteria has been postulated as the cause of most cases of shell 
disease, but experimental reproduction of the disease under controlled conditions can be difficult, even when large doses of the bacterial pathogens are used (Cook \& Lofton 1980, Johnson 1983). This suggested to us that the status of host defenses may be critical to the development of shell disease

Crustaceans and other invertebrates do not have a specific immune response (i.e. antibody or true lymphocytes) and instead rely on relatively non-specific, broad-spectrum defenses, such as phagocytosis, encapsulation and nonspecific defensive molecules (Fries 1984, Chadwick \& Dunphy 1986). Antibacterial activity has been identified in many invertebrates, including several crustaceans (Fries 1984). Here, we show that depressed levels of antibacterial activity in blue crabs coincided with an increased prevalence of shell disease.

\section{MATERIALS AND METHODS}

Bacterial cultures. Carapaces from blue crabs collected in the Pamlico River and Core Sound, North Carolina (Fig. 1), were sampled bacteriologically by scraping a small area of shell with a $1 \mu$ disposable plastic loop. This sample was rubbed onto a small area of a plate having trypticase soy agar with $5 \%$ defibrinated sheep blood. The sample was then spread on the plate using a sterile swab (Mini-tip culturette, Marion Scientific). All samples of clinically normal shell were taken from the right dorsal carapace. Cultures were incubated at room temperature. Predominant colonies were picked, purified by restreaking 3 times, and identified using API identification systems (Analytab Products, Plainview, NY, USA), as well as standard tube tests for confirmation of some reactions. All isolates were also tested for chitinase and lipase activity using standard procedures (Colwell \& Wiebe 1970, Cipriani et al. 1980).

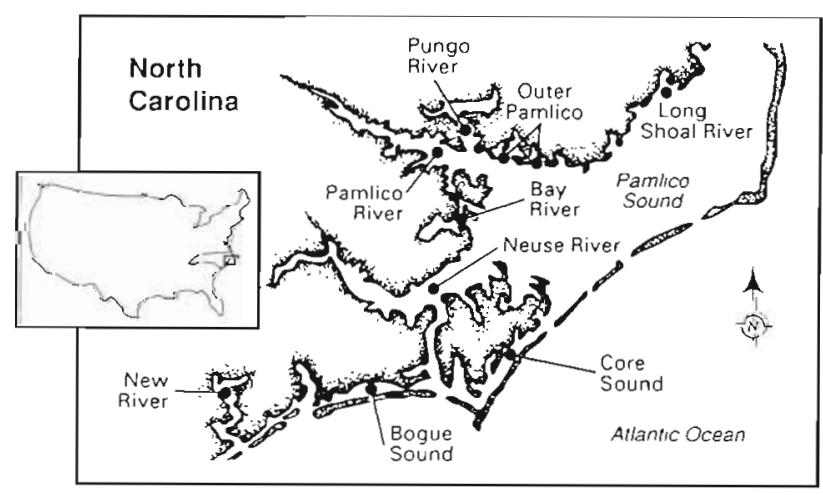

Fig. 1. Sites in the Albemarle-Pamlico Estuary, North Carolina, USA, where blue crabs were collected in this study
Animal and tissue collections. Blue crabs were collected by trawling and individual hemolymph samples were collected on site by drying the pereiopod, severing it at the merepodite, and allowing the hemolymph to clot in a tube. After clotting overnight at $4{ }^{\circ} \mathrm{C}$, the serum was separated by centrifugation at $30000 \times \mathrm{g}$, filtered through a $0.22 \mu \mathrm{m}$ filter, and stored at $-70^{\circ} \mathrm{C}$. Samples were stable for over $1 \mathrm{yr}$ and did not lose activity after freezing and thawing.

In comparing the susceptibility of various crab bacterial isolates to hemolymph, we used a known, strongly positive hemolymph sample produced from a pool of hemolymph from 10 Core Sound crabs. Bacteria were rapidly screened for susceptibility to antibacterial activity by streaking the isolates onto trypticase soy agar with $1 \% \mathrm{NaCl}$. Ten $\mu$ l of filtered hemolymph or sterile seawater was immediately spotted onto the plates, which were incubated at room temperature. Inhibition of growth was indicated by the presence of a clear zone where hemolymph was spotted. Seawater did not inhibit growth of any isolates.

Antibacterial assay. To quantify differences in antibacterial activity among individual crabs, we developed a turbidometric assay based upon the method of Anderson \& Chain (1982). Escherichia coli D31, a bacterium that is commonly used to measure antibacterial immune responses in insects (Boman \& Hultmark 1987), was used for this quantitative assay. An overnight culture of $E$. coli D31 incubated in trypticase soy broth with $1 \% \mathrm{NaCl}$ (TSB/NaCl) was washed and diluted in phosphate buffer ( $\mathrm{pH} 7.2)$ with $1 \% \mathrm{NaCl}$ to an $\mathrm{OD}_{570}$ of $\sim 0.100$. This suspension was diluted $1: 100$ with buffer. A $2 \mu$ sample of each crab hemolymph was added to $38 \mu \mathrm{l}$ of buffer. Ten $\mu \mathrm{l}$ of bacterial suspension was added and the tubes were incubated for $30 \mathrm{~min}$ at $25^{\circ} \mathrm{C}$. Controls included tubes where buffer or a known, strongly positive hemolymph sample were substituted for the test hemolymph sample and samples that had no bacteria added. The reaction was simultaneously stopped by placing all tubes in a $4{ }^{\circ} \mathrm{C}$ water bath; $450 \mu \mathrm{l}$ of $4{ }^{\circ} \mathrm{C} \mathrm{TSB} / \mathrm{NaCl}$ was then added to all tubes. Aliquots $(100 \mu \mathrm{l})$ of each sample were added to quadruplicate wells of a 96 -well tissue culture plate. The optical density of each well was recorded using an automated spectrophotometer (Dynatech MR 700, Chantilly, VA, USA) when the optical density of the negative control cultures (having bacteria but no hemolymph) reached an $\mathrm{OD}_{570}$ of 0.090 to 0.110

Statistical analysis. Hemolymph samples were collected from over 350 crabs between July and November of 1988 and 1989. Our initial statistical analyses suggested that male crabs collected from the same geographic site may differ in antibacterial activity from females collected from the same site. Since fewer females were collected, all subsequent analyses were 
performed using intermolt (between stages $\mathrm{C} 1$ und D1) males. For comparison of different geographic sites, we only used crabs without shell disease.

We did not randomly assign samples from various sites on each individual plate. This necessitated the use of controls to assure that run-to-run variation was not a confounding variable. The effects of geographical location, date of collection and presence versus absence of shell disease were examined by the use of a simple linear model (PROC-GLM function, SAS Institute, Cary, NC) which included an effect for each of these factors. The positive (strong hemolymph sample) and negative (buffer) control variables were used as covariates in this model as well. When raw data were used in this analysis, there was an increase in the difference between the actual and predicted values as the relative optical density values increased (i.e. there were more outliers in the high optical density samples). This indicated that the model was a poor fit. This prompted us to perform a natural log transformation of all data points in order to correct for the observed multiplicative variation (i.e. higher variation with higher values). In order to log-convert the data, all zero values had to be increased by a small factor. The model was run using a range of small correction factors added to the values, as well as only to the zero values, in order to identify any significant skewing of the data resulting from this procedure. The result was that small values between 0.0001 and 0.001 did not significantly affect the data set; thus, a factor of 0.0005 was added to all values.

The converted data were analyzed using the same model as previously mentioned. The results were that the positive and negative control variables did not have any significant effect on the model, indicating that the assay and specifically the positive and negative controls were very consistent. There was also no significant effect of sample collection date, which prompted us to remove the control covariant and the sample collection date from the model. Pairwise tests using least squares means were performed, and least squares means and their standard errors were computed. These tests are relevant only when interest focuses on the particular pair of means in question, and are not to be combined to make inference on how all means compare with each other. In this work, this issue was addressed by the regression analysis described below. The antilog of all resulting data outputs were taken in order to return the values to the original scale. Most of the outliers in the data set were on the high side of the model curve; since outliers were not weighted as heavily by the model as were the points closer to be curve, the values were shifted lower. However, they are a close estimate of the predicted values on the original scale.
To determine if there was a trend in level of antibacterial activity with change in salinity, regression analysis was used to investigate the trend. Based on graphical examination of the relationship, a straight line model was used as a parsimonious empirical model for trend

\section{RESULTS}

\section{Clinical appearance of shell disease}

Blue crabs in the Albemarle-Pamlico Estuary develop severe shell disease with erosive lesions that extend through the shell, exposing soft tissues (Fig. 2). In severe cases, as much as $25 \%$ of the dorsal aspect of the carapace may be eroded away. All clinical cases of shell disease included in this study had at least one lesion of $100 \mathrm{~mm}^{2}$ or larger in area. We defined clinically normal crabs as individuals that did not have this type of shell disease lesion. We observed a few small, 'burn spot' type shell lesions (Rosen 1970) in virtually all crabs sampled. Crabs with only 'burn spot' type lesions were considered clinically normal.

\section{Characteristics of shell microflora}

Heavy bacterial growth was present in most samples isolated from both clinically normal carapace and shell disease lesions. Most isolates were from the genera Vibrio, Pseudomonas, Aeromonas, or Plesiomonas. Vibrios were predominant in the high salinity sites, while aeromonads and pseudomonads were most common in low salinity sites. Of the bacteria isolated from shell disease lesions of Pamlico River crabs, 52\% $(11 / 21)$ were lipase-positive and $14 \%(3 / 21)$ were chitinase-positive. Of the isolates from clinically normal shells of Pamlico River crabs, $48 \%(10 / 21)$ were lipasepositive and $14 \%(3 / 21)$ were chitinase-positive. Of the bacteria isolated from clinically normal shells of Core Sound crabs, 96\% (26/27) were lipase-positive and $41 \%(11 / 27)$ were chitinase-positive.

\section{Eifect of hemolymph on bacterial microflora}

Blue crab hemolymph inhibited many shell-dwelling bacteria. Of the bacteria isolated from shell disease lesions of Pamlico River crabs, 52\% (11/21) were susceptible to hemolymph. Of the isolates from clinically normal shells of Pamlico River crabs, 57\% (12/21) were susceptible to hemolymph. Of bacteria isolated from clinically normal shells of Core Sound crabs, $52 \%$ $(14 / 27)$ were susceptible to hemolymph. 

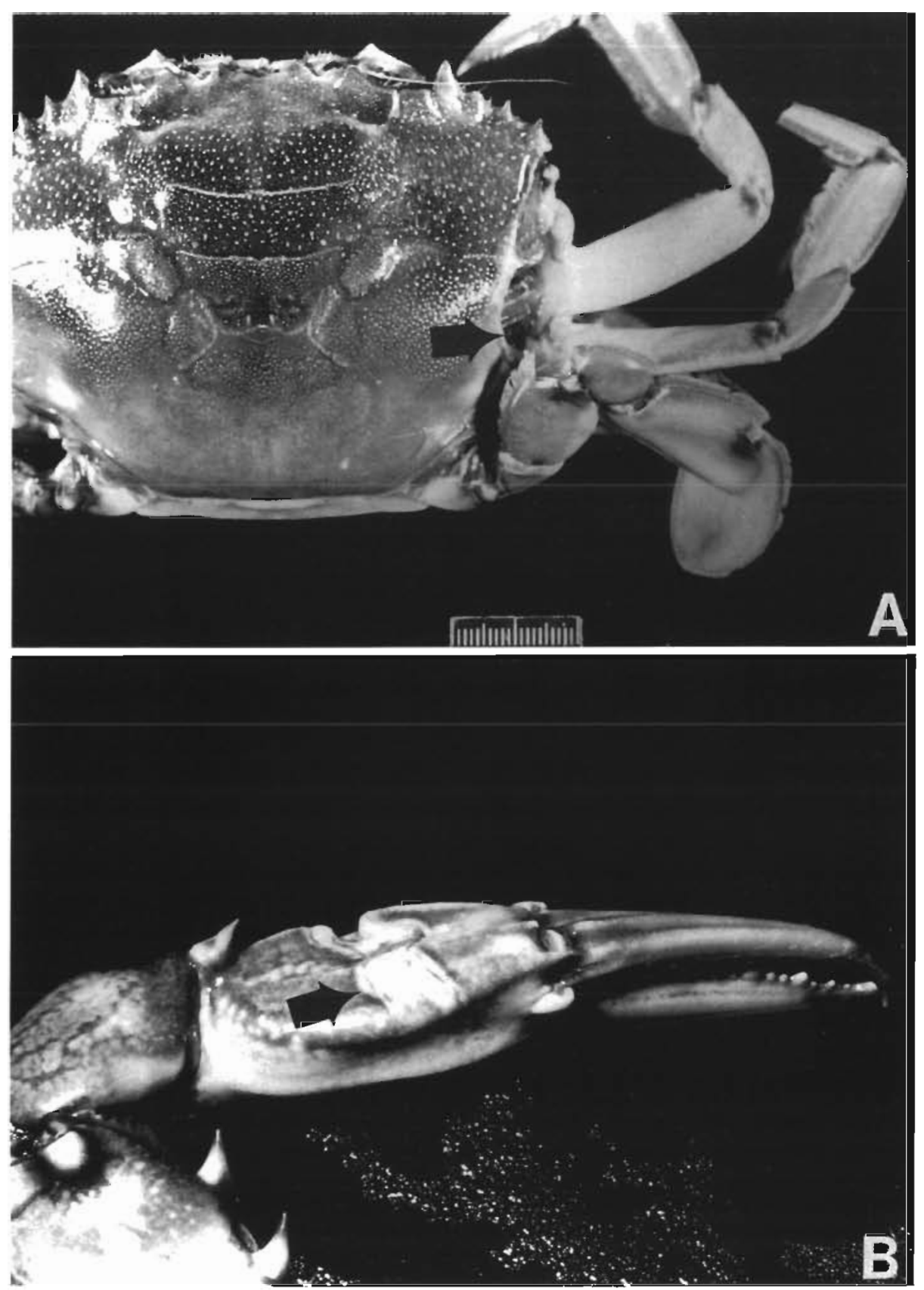

Fig. 2. Callinectes sapidus. Typical shell disease lesions in blue crabs collected from the Pamlico River. (a) Complete erosive loss of the right dorsal spine (arrow). (b) Deep erosive lesion on the right cheliped (arrow)

\section{Site and health-related differences in antibacterial activity}

We measured the hemolymph antibacterial activity of blue crabs from 8 different sites in the AlbemarlePamlico Estuary (Table 1, Fig. 1), including the Pamlico, Pungo and Neuse Rivers, where shell disease epidemics have recently been observed (McKenna et al. 1988). Antibacterial activity was lowest in the more riverine sites, with the Pungo, Pamlico, Bay and Neuse Rivers having significantly lower activity than the more oceanic Core and Bogue Sound sites (Fig. 3). All of the crabs collected at the latter 2 sites were clinically normal. Furthermore, Pamlico River blue crabs with shell disease had significantly $(p<0.05)$ lower antibacterial activity $\left(O D_{570}=0.0201, N=20\right)$ than their clinically normal cohorts $\left(O D_{570}=0.0054, N=76\right)$.

A simple linear regression model was used as a model for trend. The model was fitted to the transformed data to determine whether a model that incorporates a straight line relationship, suggesting an association between salinity and antibacterial level, was a better model than just a single mean, taking no account of salinity. 
Table 1. Raw data means for serum samples collected from various sites illustrated in Fig. 3

\begin{tabular}{|lcccc|}
\hline Site & Salinity & $\mathrm{N}$ & Mean $\mathrm{OD}_{570}$ & $\mathrm{SD}$ \\
\hline $\mathrm{PU}$ & 9 & 19 & 0.029211 & 0.029996 \\
$\mathrm{PA}$ & 9 & 76 & 0.019840 & 0.026105 \\
BR & 10 & 23 & 0.020739 & 0.026018 \\
NR & 11 & 17 & 0.020294 & 0.0281 .24 \\
PO & 14 & 28 & 0.009929 & 0.018649 \\
LR & 17 & 20 & 0.013000 & 0.021589 \\
CS & 34 & 27 & 0.002704 & 0.005716 \\
BS & 35 & 16 & 0.007000 & 0.013599 \\
\hline
\end{tabular}

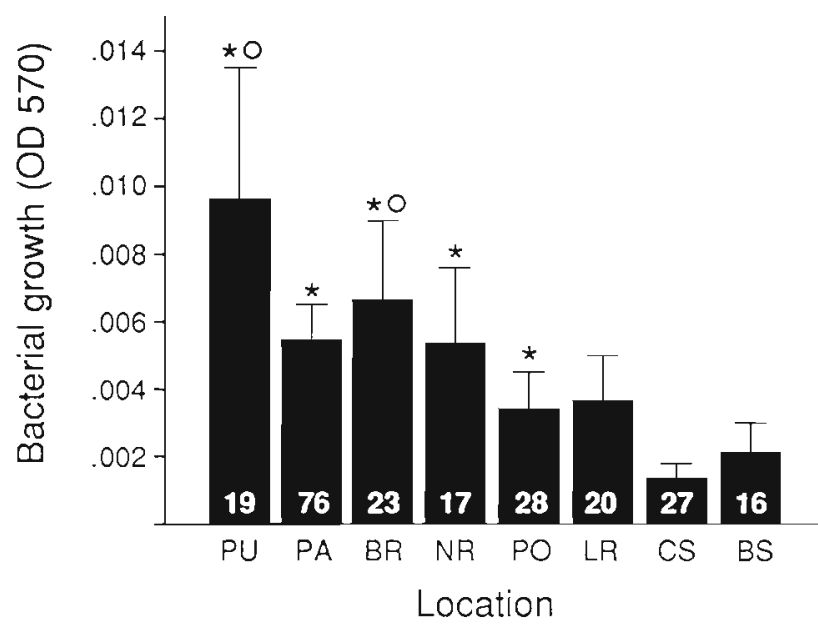

Fig. 3. Callinectes sapidus. Antibacterial activity of intermolt, clinically normal male blue crabs collected from different geographic locations in the Albemarle-Pamlico Estuary ( $+1 \mathrm{SE}$. Values are expressed as the concentration of Escherichia coli D31 bacteria present after exposure to hemolymph followed by a standardized incubation period in culture medium. Thus, the lowest bacterial growth indicates the highest antibacterial activity. Values are expressed as predicted least square means, as described in the text. ( $\star$ ) Values differ significantly from mean activity of Core Sound crabs; (O) values differ significantly from mean activity of Bogue Sound crabs $(p<0.05)$. No other values are significantly different from each other. Ranking of sites is from lowest (Pungo River) to highest (Bogue Sound) mean salinity based upon hydrographic data of Wood (1967). Numbers in the bars are the total number of individual crabs sampled. BR: Bay River; BS: Bogue Sound; CS: Core Sound; LR: Long Shoal River; NR: Neuse River; PA: Pamlico River; PO: outer Pamlico River (includes Rose Bay and Swanquarter Bay); PU: Pungo River

The transformed rather than raw data were used to satisfy the requirement of constant variance in regression analysis. On the original scale, the data exhibited high coefficients of variation (CV) at all salinity levels, as can be seen from Table 1. On the transformed scale, CVs were in the range from 20 to $40 \%$ across the response range, so that the logarithmically scaled data were less variable. In all model fits, residuals were plotted against predicted values from the fit to ensure that the constant variance assumption required for the validity of hypothesis tests was not violated. No graphical evidence of violation was observed, as the plots showed no systematic trends such as a 'fan' shape indicating nonheterogeneous, increasing variation across the response range. Thus, it was reasonable to apply the usual regression analysis techniques to the transformed data. The fitted model, based on 226 pairs of corrected data-salinity values, was: transformed, corrected data $=-4.6619-0.05282 \times$ salinity

Because several observations are available at each salinity level, it was possible to calculate a sample mean at each. Thus, an initial question was whether it was possible to capture the salient features of trend with a straight line, or whether a less parsimonious model consisting of means at each salinity levels would be required. This was addressed by the test commonly referred to as a 'lack-of-fit' test. The test was insignificant ( $p=0.87$, on 1 and $6 \mathrm{df}$ ), indicating that the data did not contain sufficient evidence to indicate that the more sophisticated model was an improvement over the straight line representation.

Given the result of the lack-of-fit test and the fact that the regression mean square was substantially larger than that for lack-of-fit, the test for the significance of the regression was performed based on the error mean square consisting of the pooled lack-of-fit and pure error sums of squares; that is, the usual $F$ test. This test of whether the slope of the assumed straight line relationship was zero resulted in a value of $-4.295(p<0.001) m$ which consists of a single mean. As a further check, a quadratic model was fit to assess whether a subtle curvature in the trend relationship might be present. There was not sufficient evidence to suggest that this model explains more of the variation in the data than the straight line alone.

From the plot of the raw data, a straight line model seems to be a reasonable empirical representation of trend, albeit with the variation present along the straight line relationship. These data suggest a negative association between log-transformed optical density values and salinity.

\section{DISCUSSION}

Bacteria which we isolated from clinically normal crabs as well as those with shell disease included agents, such as Vibrio spp. and Pseudomonas spp., which have been commonly reported from shell disease lesions (Cook \& Lofton 1973, Cipriani et al. 1980). Many of these agents are also common in estuarine waters (Hood \& Myers 1974) and thus do not appear to be obligate pathogens. All the bacteria which we isolated from shells of both clinically normal blue crabs 
and those with shell disease had either lipase or chitinase enzymes; some had both enzymes. These biochemical markers have been traditionally associated with shell disease pathogens (Cook \& Lofton 1973, Cipriani et al. 1980). However, these enzymatic activities are also common properties of many marine bacteria (Lear 1963, Hood \& Myers 1974); thus, the mere presence of bacteria with these enzymatic activities is probably not responsible for the development of shell disease.

There was a gradient of decreasing antibacterial activity from the oceanic to the riverine areas of the Albemarle-Pamlico Estuary (Fig. 3). Many environmental and biological factors vary along this oceanicriverine gradient, the most obvious being salinity. However, salinity changes, as influenced by runuff, tidal flow and other factors, are also associated with other ecological differences.

Differences in immunocompetence might be due to pollution, which may impact the riverine ecosystems more severely, since they are closest to the initial discharge of many substances. Many water-quality problems, including hypoxia, increased turbidity, and heavy metal contamination have been identified in these low salinity areas (Rader et al. 1987). This might explain why shell disease is more common in the riverine areas. Other diseases besides shell disease may be affecting the crabs in the riverine areas which may affect their immunocompetence. Alternatively, blue crabs in the riverine areas may normally have lower antibacterial activity, due to presently unknown physiological changes that are associated with adaptation to this particular environment. For example, the naturally large fluctuations of many factors (salinity, etc.) in the riverine ecosystems may cause a reduction in immunocompetence.

Nutritional differences due to prey abundance or other factors may be important. Fisher et al. (1976) found that inadequate nutrition caused shell disease in cultured lobsters Homarus americanus and Stewart et al. (1967) found that inadequate nutrition caused a reduction in hemocyte numbers in lobsters. Most, if not all, of the blue crab antibacterial activity resides in the hemocytes, not the plasma (Noga \& Arroll unpubl.) and our preliminary data suggest that hemocyte numbers are also depressed in Pamlico River blue crabs (Noga, Stevens \& Arroll unpubl.).

Even if lower antibacterial activity in riverine crabs is ecophysiologically normal, it may still explain why blue crabs in the riverine parts of the ecosystem show a higher prevalence of shell disease. It could also imply that these riverine ecosystems may be especially vulnerable to added stressors associated with pollution Since the early 1980s, there has been a substantial decline in recruitment and landings of blue crabs in the
Pamlico River, while landings in Pamlico Sound have remained stable (U. S. National Marine Fisheries Service unpubl. data). Undiscovered diseases in these young crab populations may be reponsible for lack of recruitment. Interestingly, the riverine areas of the Albemarle-Pamlico Estuary have been plagued by not only a high prevalence of shell disease but also fish disease epidemics that have been associated with opportunistic fungal infections (Levine et al. 1990. Noga 1993).

Our data suggest that hemolymph antibacterial activity may be an important source of chemicals for defending against shell disease. Invading shell disease pathogens are clearly exposed to hemolymph once shell integrity has been breached and lesions reach the epithelium. However, even intact shell might be protected by hemolymph activity. The crustacean shell consists of an outer epicuticle containing lipid, protein and calcium salts, a middle procuticle consisting mostly of chitin, protein and calcium salts and an inner epidermis (Stevenson 1985). The carapace is acellular except for the epidermis. Intact immune cells do not inhabit the epicuticle or procuticle (Stevenson 1985), but ducts of the tegumental glands extend to the surtace of the cuticle which could allow the transport of defensive chemicals. These glands contain antibacterial agglutinins (Stagnen \& Redmond 1975), phenoloxidase (Stevenson \& Schneider 1962) and phenols (Stevenson 1985) in some arthropods.

Injecting fluorescein dye (200 $\left.\mathrm{mg} \mathrm{kg}^{-1}\right)$ into blue crab hemolymph results in the uptake of dye into the shell of clinically normal crabs within 30 min (Noga \& Nasisse unpubl.), suggesting that substances may be rapidly transported into the shell from the hemolymph. Further studies will be needed to demonstrate the mechanisms responsible for transport of defensive substances into the intact blue crab shell and whether such mechanisms are important in protecting against shell disease.

The blue crab antibacterial activity is very stable, making it attractive for field sampling. The test which we developed for measuring antibacterial activity is highly reproducible and allows the testing of multiple samples simultaneously. We are in the process of biochemically characterizing this activity. The activity differs from the agglutinin described by Pauley (1973) in that the bactericidin is less active at high $\mathrm{pH}$ and totally inactivated by proteolysis (Noga \& Arroll unpubl.).

It is important to note that we only used Escherichia coli D31 for quantitative determination of antibacterial activity because this bacterium's response was highly reproducible and it was very susceptible to the antibacterial activity. This may be because it is a lipopolysaccharide-deficient mutant and thus is highly sensi- 
tive to membrane-active antibiotics (Boman et al 1974). We feel that using $E$. coli D31 was an appropriate choice, given the fact that over $50 \%$ of all crab isolates were sensitive to the bactericidal activity in hemolymph. It is appropriate to use a highly sensitive bacterial species as a model because one is measuring a nonspecific immune response and not a highly specific response, such as antibody production. While different bacterial species vary in their susceptibility to bactericidins, we were measuring relative differences in our study.

There is a need for biomarkers that are useful indicators of aquatic animal health (Green 1984, Giam et al. 1987), especially those that can identify sublethal changes in ecological systems that may be predictors of deleterious effects (Capuzzo et al. 1988). In this way, problems may be abrogated before serious damage occurs. While many types of physiological and biochemical tests, such as enzyme levels and clinical pathology changes have been measured in natural aquatic populations (Hinton \& Couch 1984, Neff 1985, Couch 1988), the significance of these changes to the health or survival of the population at risk is often unclear (Mehrle \& Mayer 1985). While a cause-and-effect relationship has not been proven, our results represent one of the first times that a subclinical biomarker has been directly linked to risk of clinical disease in an aquatic population.

Acknowledgements. We thank the staff of the North Carolina Division of Marine Fisheries for generous assistance in collecting crabs. We also thank J. Hawkins, N. West, P. Johnson, M. Levy and J. A. Couch for helpful discussions. Supported by the Environmental Protection Agency through the Albemarle-Pamlico Estuarine Study under Grant No. 90-20.

\section{LITERATURE CITED}

Anderson, R. S., Chain, B. M. (1982). Antibacterial activity in the coelomic fluid of a marine annelid, Glycera dibranchiata. J. Invert. Pathol. 40:320-326

Boman, H. G., Hultmark, D. (1987). Humoral immune factors in insects. A. Rev. Microbiol. 41: 103-145

Boman, H. G., Nilsson-Faye, I., Paul, K., Rasmuson, T. (1974). Insect immunity I. Inducible, cell-free antibacterial reaction in hemolymph of Samia cynthia pupae. Infect. Immun. 10: $136-145$.

Capuzzo, J. M., Moore, M. N., Widdows, J. (1988). Effects of toxic chemicals in the marine environment: predictions of impacts from laboratory studies. Aquat. Toxicol. 11: 303-311

Chadwick, J. S., Dunphy, G. B. (1986). Antibacterial and antiviral factors in arthropod hemolymph. In: Gupta, A. P. (ed.) Hemocytic and humoral immunity in arthropods. John Wiley and Sons, New York, p. 287-330

Cipriani, G. R., Wheeler, R. S., Sizemore, R. K. (1980). Characterization of brown spot disease of Gulf Coast shrimp. J. Invert. Pathol. 36: 255-263

Colwell, R. R., Wiebe, W. J. (1970). 'Core' characteristics for use in classifying aerobic, heterotrophic bacteria by numerical taxonomy. Bull. Ga Acad. Sci. 28: 165-185

Cook, D. W., Lofton, S. R. (1973). Chitinoclastic bacteria associated with shell disease in Penaeus shrimp and the blue crab Callinectes sapidus. J. Wildl. Dis. 9: 154-159

Couch, J. A. (1988). Role of pathobiology in experimental marine biology and ecology. J. exp. mar. Biol. Ecol. 118: 1-6

Engel, D. W., Noga, E. J. (1989). Shell disease in blue crabs of the Pamlico River. Environs 12: 3-5

Fisher, W. S., Rosemark, T. R., Nilson, E. H. (1976). The susceptibility of cultured American lobsters to a chitinolytic bacterium. Proc. World Maricult. Soc. 7: 511-520

Fries, C. R. (1984). Protein hemolymph factors and their roles in invertebrate defense mechanisms. In: Cheng, T. C. (ed.) Comparative pathobiology, Vol. 6. Plenum Press, New York, p. 49-109

Giam, C. S., Ray, L. E., Anderson, R. S., Fries, C. R., Lee, R., Neff, J. M., Stegeman, J. J., Thomas, P., Tripp, M. R. (1987). Pollutant responses in marine animals: the program. In: Giam, C. S., Ray, L. E. (eds.) Pollutant studies in marine animals. CRC Press, Boca Raton, p. 1-21

Gopalan, U. K., Young, J. S. (1975). Incidence of shell disease in shrimps of the New York Bight. Mar. Pollut. Bull. 6: $149-153$

Green, R. H. (1984). Some guidelines for the design of monitoring programs in the marine environment. In: White, $\mathrm{H}$. H. (ed.) Concepts of marine pollution. Maryland Sea Grant, College Park, p. 647-655

Hinton, D. E., Couch, J. A. (1984). Pathobiological measures of marine pollution effects. In: White, H. H. (ed.) Concepts of marine pollution. Maryland Sea Grant, College Park, p. $7-32$

Hood, M. A., Myers, S. P. (1974). Distribution of chitinoclastic bacteria in natural estuarine waters and aquarial systems. In: Amborski, R. S., Hood, M. A., Miller, R. R. (eds.) Prodeedings of the Gulf Coast Regional Symposium on Diseases of Aquatic Animals. Louisiana State Univ. Publ No. LSU-SG-74-05, Baton Rouge, p. 115-121

Johnson, P. T (1983). Diseases caused by viruses, bacteria rickettsia, and fungi. The Biology of Crustacea $6: 1-78$

Lear, D. W. (1963). Occurrence and significance of chitinoclastic bacteria in pelagic water and zooplankton. In Oppenheimer, C. (ed.) Symposium on marine microbiology. Charles Thomas, Springfield, IL, p. 594-610

Levine, J. F., Hawkins, J. H., Dykstra, M. J., Noga, E. J., Cone, R. S., Moye, D. (1990). Species distribution of ulcerative lesions on finfish in the Tar-Pamlico River Estuary, North Carolina. Dis. aquat. Org. 8: 1-5

McKenna, S., Jansen, M., Pully, M. (1988). Shell disease of blue crabs, Callinectes sapidus, in the Pamlico River, North Carolina. North Carolina Division of Marine Fisheries Special Scientific Report No. 51, Washington NC

Mehrle, P. M., Mayer, F. L. (1985). Biochemistry/physiology. In: Rand, G. M., Petrocelli, S. R. (eds.) Fundamentals of aquatic toxicology. Hemisphere Publishing Corp., New York, p. 264-282

Murchelano, R. A. (1982). Some pollution-associated diseases and abnormalities of marine fishes and shellfishes: a perspecitve for the New York Bight. In: Mayer, G. F. (ed.) Ecological stress and the New York Bight. Estuarine Research Federation, Columbia, SC, p. 327-346

Neff, J. M. (1985). Use of biochemical measurements to detect pollutant-mediated damage to fish. In: Cardwell, R. D. Purdy, R., Bahner, R. C. (eds.) Aquatic toxicology and hazard assessment. American Society for Testing and Materials, Philadelphia, p. 155-183 
Noga, E. J. (1993). Fungal diseases of marine and estuarine fishes. In: Couch, J. A. (ed.) Pathobiology of marine and estuarine animals. Van Nostrand Rheinholt, New York, p. $85-110$

Pauley, G. B. (1973). An attempt to immunize the blue crab Callinectes sapidus with vertebrate red blood cells Experientia 29: 210-211

Rader, D. F., Loftin, L. F., McGee, B. A., Dorney, J R. Clements, J. T (1987). Surface water quality concerns in the Tar-Pamlico Basin. North Carolina Division of Environmental Management Water Quality Rep. No. 87-04

Rosen, B. (1970). Shell disease of aquatic crustaceans. In Snieszko, S. F. (ed.) A symposium on diseases of fishes and shellfishes, Spec. Publ. No. 5, American Fisheries Soc. Washington, DC, p. 409-415

Sindermann, C. J. (1989). The shell disease syndrome in marine crustaceans. NOAA Tech. Memo. NMFS-F/NEC64

Sindermann, C. J (1990). Principal diseases of marine fish and shellfish, Vol. 2. Academic Press, New York

Stangen, J. I., Redmond, J. R. (1975). The immunological

Responsible Subject Editor: J. E. Stewart, Dartmouth. NS., Canada mechanisms of the horseshoe crab Limulus polyphemus. Mar. Fish. Rev. 37: 11-19

Stewart, J. E., Cornick, J. W., Dingle, J. R. (1967). An electronic method for counting lobster (Homarus americanus Milne Edwards) hemocytes and the influence of diet on hemocyte numbers and hemolymph proteins. Can. J. Zool. 45: $291-304$

Stevenson, J. R. (1985). Dynamics of the integument. The Biology of Crustacea 9: 1-42

Stevenson, J. R., Schneider, R. P. (1962). Tyrosinase activity of organs containing tegumental glands in the crayfish. J. exp. Zool. 150: 17-25

Taylor, C. C. (1948). Shell disease as a mortality factor in the lobster. State of Maine Dept of Sea and Shore Fisheries, Fisheries Circular No. 4

Wood, W. J. (1967). Hydrographic studies in Pamlico Sound. Proc. Symp. on Hydrol. of the Coastal Waters of North Carolina. Univ. of North Carolina Waters Resources Research Institute Rept No. 5

Young, J. S, Pearce, J. B. (1975). Shell disease in crabs and lobsters from the New York Bight. Mar. Pollut. Bull. 6: $101-105$

Manuscript first received: July 24, 1991

Revised version accepted: March 6, 1994 